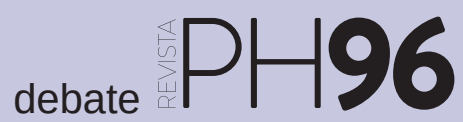

\title{
Cuando la memoria deja de estar en blanco y negro: las exposiciones participativas del museo de La Rinconada
}

\author{
Maribel Rodríguez Achútegui | museo de La Rinconada (Sevilla) \\ URL de la contribución <www.iaph.es/revistaph/index.php/revistaph/article/view/4322>
}

Me gustaría comenzar aclarando que los responsables de la actividad que nos ocupa no somos especialistas en memoria democrática. En realidad la línea de trabajo de la que hablamos se realiza desde el museo de La Rinconada, donde contamos con una colección arqueológica y paleontológica, aunque funciona como la institución patrimonial (en sentido amplio) de la localidad. Eso sí, desde la Delegación de Cultura y Memoria Histórica del Ayuntamiento de La Rinconada (Sevilla) se lleva ya mucho tiempo realizando trabajos como el catálogo de símbolos de exaltación del franquismo ${ }^{1}$, que ha permitido su posterior retirada, así como la colaboración con asociaciones memorialistas en diferentes jornadas y eventos. Ambas instituciones nos propusimos el objetivo de acercar estas temáticas a personas que no son habituales en las actividades memorialistas. En el análisis que realizamos nos pareció especialmente interesante dirigirnos a adolescentes puesto que, por una parte, están en la fase de creación de su ideario $y$, por otra, ejercen de amplificadores hacia sus familias y amistades.

Nuestras experiencias anteriores con este público nos llevaron a decidirnos por la metodología participativa, como forma de implicación de un colectivo que prefiere ser protagonista antes que receptor pasivo. Nuestra propuesta fue que un grupo de adolescentes realizara los trabajos necesarios para hacer una exposición en el museo sobre el Canal de los Presos, un gran obra de ingeniería realizada con los presos políticos de la represión franquista, para transformar en regadíos parte de las tierras del Bajo Guadalquivir y que en su trazado atraviesa nuestro término municipal.

La premisa de partida fue que las chavalas y chavales tendrían la autoría de la exposición y, por lo tanto, serían responsables del resultado final. Para el equipo del museo, esto suponía aceptar sus decisiones, aunque a veces no coincidieran con nuestro criterio, y comprometernos a vestir su trabajo para que el resultado fuera lo más profesional posible.

Contactamos con uno de los institutos de la localidad, el instituto de educación secundaria San José, y comenzamos los trabajos con el grupo de $3 .^{\circ} \mathrm{A}$ de la ESO, en colaboración con su profesor de historia Francisco Rivera Aguilar. Asimismo, para implicar al máximo número de personas, invitamos también al taller de fotografía de La Rinconada "Factoría creativa", quienes se prestaron inmediatamente a que el resultado de su trabajo artístico completara la exposición, con un conjunto de fotografías del canal. Finalmente la Asociación Comarcal Pro-Memoria Democrática Vega Media del Guadalquivir nos aportaría un contexto histórico a modo de introducción de la exposición y la Asociación Memoria, Libertad y Cultura Democrática nos ayudó facilitando las imágenes históricas y su interpretación del recorrido del canal y elementos significativos ${ }^{2}$.

Nos planteamos que el proceso tenía que conseguir que, por una parte, quienes participaban reflexionasen sobre la temática de la memoria democrática y, por otra, que lo hablaran en familia. Para ello les propusimos que hicieran una primera búsqueda de información tanto preguntado a adultos como en la red, y que nos contaran lo que más les había impresionado o interesado del tema. De la puesta en común de sus inquietudes salieron los cinco temas que se abordarían en la exposición, que iban desde el por qué de ese canal a las condiciones de vida de los presos, las consecuencias para las familias o las barriadas que surgieron en torno a los campos de concentración. 
a debate Memoria democrática en la construcción de la historia y el patrimonio

| coordina Josefina Cuesta Bustillo

A partir de aquí, 5 grupos de trabajo se encargaron de desarrollar cada uno de estos temas, seleccionar aquellos conceptos que les parecían más importantes y buscar información y apoyos gráficos. Por otra parte, desde el museo nos encargamos de rematar la redacción expositiva, aportar el diseño gráfico y ocuparnos de la producción final.

Llegado el día de la inauguración, se invitó a la comunidad educativa, asociaciones participantes y por supuesto a las familias y amigos del grupo autor. Se intentó dar la máxima importancia al evento, tanto en prensa y radio local, como con la presencia en la inauguración del alcalde y la delegada de Cultura y Memoria Histórica. Las chicas y chicos se enfrentaron a los micrófonos y cada grupo presentó las conclusiones de sus trabajos.

De todo este proceso lo que más nos llamó la atención a las personas que tutorizábamos los trabajos fue la gran perplejidad de esa generación, nacida y criada en democracia, ante la realidad de que el único delito de estos presos castigados con trabajos forzados había sido el pensar de forma diferente que los vencedores de la guerra.

Desde el museo hemos continuado con esta línea de trabajo $y$, tras esta primera exposición, hemos realizado en años sucesivos Tras-pasar la frontera: El exilio republicano y iAndaluces levantaos! De la dictadura a la autonomía andaluza. En la actualidad estamos preparando una nueva exhibición, en colaboración con el Centro de Estudios Andaluces, sobre la represión franquista, para la que ya estamos trabajando con dos institutos de la localidad y esperamos que se incorporen los dos restantes.

Para nosotros es muy importante destacar sobre todo algunas ideas que extraemos de la evaluación que nos hizo el alumnado participante. Por una parte, nombraron mucho la cercanía; les había impresionado que todo esto hubiera ocurrido, aquí, en nuestro pueblo. Por otro, descubrimos que, en muchos casos, era la primera vez que lo hablaban en su familia. Finalmente otra idea recu-

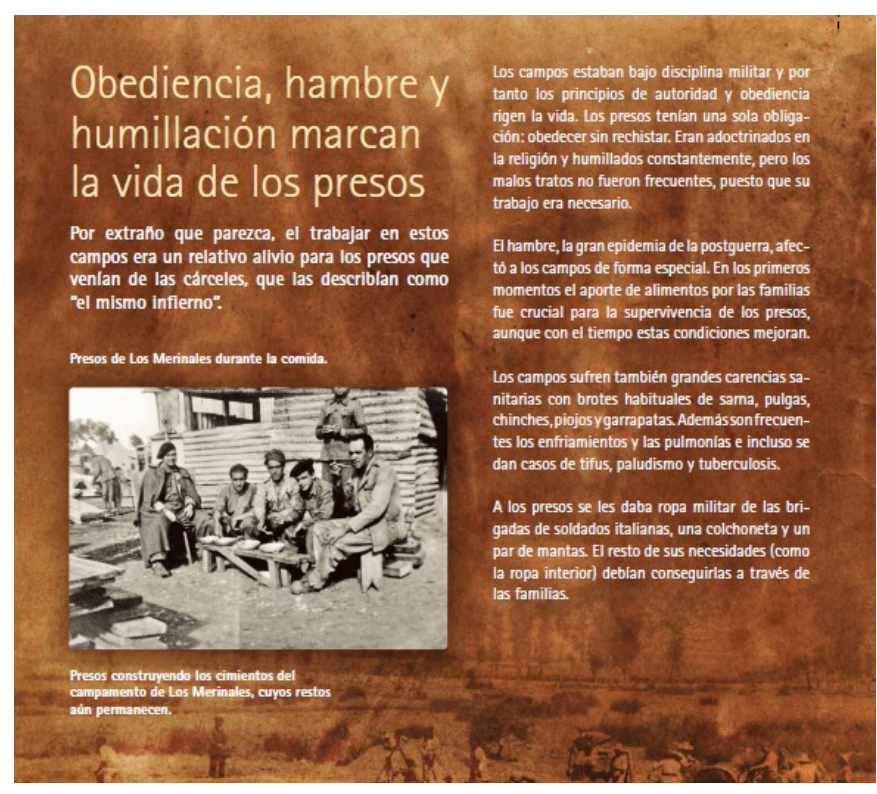

Detalle de uno de los paneles de la exposición | foto Fondo Espiral, Animación de Patrimonio

rrente la expresaré con las palabras que Lucía, una chica de 16 años, preparó para la inauguración:

“...Se nos presentó como un trabajo de historia, pero para nosotros ha dejado de ser eso. No es historia, no se ha dormido aún el pasado, algo que les sucedió a nuestros abuelos o bisabuelos. Tras las estadísticas y documentos que estudiamos, había personas, y gracias a este proyecto de investigación, hemos eliminado el efecto 'blanco y negro' y esta historia ha dejado de ser algo antiguo y oxidado".

\section{NOTAS}

1. Lara Cervera Pozo fue la encargada de realizar este catálogo.

2. Desde aquí queremos agradecer especialmente a Gonzalo Acosta Bono su colaboración y asesoramiento. 